\title{
THE EFFECT OF MACROECONOMIC VARIABLES ON THE STOCK EXCHANGE PERFORMANCE OF REAL ESTATE INVESTMENT TRUSTS: PANEL REGRESSION ANALYSIS
}

\author{
DOI: $10.17261 /$ Pressacademia.2021.1419 \\ PAP- V.13-2021(8)-p.36-41
}

\section{Salih Durer ${ }^{1}$, Aysegul Berrak Koten ${ }^{2}$}

${ }^{1}$ Yildiz Technical University, Department of Business Administration, Istanbul, Turkey. durer@yildiz.edu.tr, ORCID: 0000-0003-2575-2842

${ }_{2}^{2}$ Yildiz Technical University, Department of Business Administration, Istanbul, Turkey. a.berrak@gmail.com, ORCID: 0000-0002-5680-9920

\section{To cite this document}

Durer, S., Koten, A. B. (2021). The effect of macroeconomic variables on the stock exchange performance of real estate investment trusts: panel regression analysis. PressAcademia Procedia (PAP), V.13, 36-41.

Permanent link to this document: http://doi.org/10.17261/Pressacademia.2021.1419

Copyright: Published by PressAcademia and limited licensed re-use rights only.

\begin{abstract}
Purpose- This study aims to reveal the effects of per capita income, housing interest rates and inflation, which are the main macroeconomic variables, on the stock market performance of real estate investment trusts (REITs), with the help of panel regression analysis.

Methodology- In this study, 27 REITs with high transaction volume and not missing data were selected and the panel regression analysis was made for the period 2014.Q1 - 2020.Q2. For the first order stationary data, the Random Effects Model was found to be suitable as a result of the Hausman test, and the Greene heteroscedasticity test and the Wooldridge autocorrelation test were analyzed to provide the assumptions.

Findings- As a result of the analysis, $0.09 \%$ per capita income to have an increasing effect, housing interest rates of $10.5 \%$ and $9.71 \%$ inflation to have a statistically decreasing effect on stock market performance indicator the market value / book value.

Conclusion- In this study, it was determined which increase in income per capita, which is one of the macroeconomic variables, affects the performance positively for the REITs in the stock market, while the increase in inflation and housing interest rates affects the performance negatively. Due to its strong links with other sectors in the economy, the real estate sector is significantly affected by the change in economic conditions, while at the same time creating significant effects on the economy. One of the important features of the real estate market is its sensitivity to macroeconomic changes. The real estate sector is seen as the locomotive of the country's economy, as it has many sub-markets and has a close relationship with many fields such as construction, finance, economy and law. For this reason, policy makers need to ensure market stability to maintain the positive effect of the variables that contribute to the increase in the stock market performance of REITs.
\end{abstract}

Keywords: REITs, stock market performance, macroeconomic variables, panel regression analysis. JEL Codes: M21, G00, C23

\section{INTRODUCTION}

The importance of Real Estate Investment Trusts (REITs) is significant in terms of directing the funds that are collected by going public to the real estate sector, as well as enabling the savers investing in real estate with limited savings to benefit from the increased values. In this way, REITs allow investors to become partners in real estates, which originally, they cannot buy alone (Ambrose \& Linneman, 2001: 142). Real estate investments are more attractive investment areas for investors Especially in developing countries because they are less risky compared to other investment areas, and provide higher returns for the investors in the long run (Kirui et al., 2014: 215). In recent years, the development of the construction sector in Turkey and the activity in the real estate sector, the construction of large projects, and the desire of investors to earn incomes by investing in real estate and in REITs require close monitoring of the performances of companies operating in this sector. For this reason, examining the financial performances of REITs contributes to analyzing the decisions of the investors better. When choosing among REIT companies, institutional investors that have the desire of investing their savings in real estate tend to prefer companies that have sustainable cash flow, accurate asset structure, by using the necessary protection mechanisms according to exchange and interest rate risks, diversifying their portfolio, and with a balanced growth rate, strong financial ratio, and high stock market performance. In this way, it is required to analyze the financial data of the companies to invest in, to determine their current situation, and to make assumptions for their futures (Agnello et al., 2018: 1770). Macroeconomic variables, which are among the determinants of all indices in Borsa Istanbul, also have effects on REIT stock market performance. The existence of the relations between REIT index returns and macroeconomic variables was reported by many researchers. In recent years, there are few studies conducted to examine the relation between these 
variables in Turkey, which formed the motivation of the present study. The present study aimed to reveal the relation between the macroeconomic variables estimated to have impacts on the REITs traded in Borsa Istanbul.

\section{LITERATURE REVIEW}

Studies that target to reveal the macroeconomic factors effective in determining the stock market performance of REITs also have a wide place in the literature. Various studies were conducted to determine the micro and macro factors affecting the stock market performance in the REIT market both in Turkey and in many countries.

Ewing and Payne (2005) examined the response of REITs returns to unexpected changes in real output growth, inflation, default risk premium, and the use of the monetary policy. Unlike the literature data, a generalized impulse response analysis technique was employed in the study, not standard impulse analysis. The advantage of this is that the theoretical results do not predict any order, and results are not dependent on the researcher's choice to rank the variables. The results, shocks to monetary policy, economic growth, and inflation cause returns in the REIT market to fall below the expected values.

Nishigaki (2007) used the monthly data of 1980:01-2006:11 in his study that analyzed the relations between the REIT index return in the USA and long-term interest rates, inflation and house prices. The Co-Integration Test and Vector Error Correction Model were used in the analyses. In conclusion of this study, it was reported that there was a positive correlation between the return of the REIT index and housing prices in the long run, and a negative correlation was also reported with the inflation rates. In other words, REIT index performance was reported to react negatively to a decrease in housing prices and an increase in inflation.

In their study, Chang et al. (2011) analyzed the effect of the maturity of the Fed Funding Rate on the housing market returns of REITs in the USA with the VAR model. They used monthly data sets for the 1975-2008 period and found that housing market returns showed a less significant but more persistent response to changes in the Fed Funding Rate than REIT returns. Another finding was that although the longer maturity structure increased the REIT returns, it decreased the returns in the housing market.

Zugul and Sahin (2015) analyzed the monthly data for 2002:01-2012:12 with the Least Squares Method and Multivariate Regression method in their study to determine the relations between the short-term deposit interest rates and inflation rates with REIT index return. As a result of the analysis, they reported a significant relation between the real estate investment trust index return and the inflation variable and significant and negative relation between the real estate investment trust index return and the deposit interest rate.

Loo et al. (2016) examined long- and short-term relationships between the REIT market and macroeconomic variables for 7 Asian countries (Hong Kong, Japan, Malaysia, Singapore, Thailand, South Africa, Taiwan) with the Johansen Co-integration and Granger Causality test. The variables of this study were REIT index returns of the countries, interest rates, inflation rates, GDP, industrial production, money supplies, and government expenditures. The dataset; however, was used as the monthly or quarterly period according to the macroeconomic variable for 2003:01-2014:12. As a result of their study, they reported a short-term causality relation between the REIT total index return variable and other macroeconomic variables.

Linck (2016) wanted to uncover the relationship between macroeconomic variables and stock returns for 2000-2010 in the Brazilian economy by analyzing the relations between real stock returns and the variables of interest rates, gross domestic product, and inflation rates using multiple regressions. The results indicated that the interest rates and gross domestic product affected the stock returns significantly, and the inflation rate had little or no effect on the stock data.

Wong (2017) analyzed the relations between closing prices of REIT stocks in the Australian stock exchange and GDP, interest rates, and inflation rates with monthly datasets for 1995-2015. According to the results of their study, they found that unexpected changes in inflation had significant negative effects on REIT performance.

Hussin et al. (2017) aimed to determine the presence of short- and long-term relations between Islamic REIT returns and macroeconomic variables in Malaysia by using the monthly datasets between 2007:01- 2013:12, which were analyzed with the Vector Autoregressive Model and Granger Causality test. As a result of their analysis, they detected that there was a positive relation between the REIT market and economic growth, but also, a negative relation was detected with inflation, money supply, Islamic investment rate and exchange rate. Also, it was concluded in the study that there was a Granger causality relation from inflation, industrial production index and money supply to REIT return.

In their study, Marfati et al. (2017) examined the time-varying effects of US monetary policy and macroeconomic news on international REIT stock returns with the Multi-Factor Asset Pricing Model for 1994:01-2016:08. The macroeconomic variables used in the study were changes in monetary policy, changes in inflation and employment. According to the results, it was found that the expected increases in Fed funds rates caused a decrease in REIT stock returns.

Pierdzioch et al. (2018) conducted a study and analyzed the REIT return-inflation relation for 1979-2016 with the BART model by using the survey data to make US monthly inflation an expected and unexpected component. They reported that expected and unexpected inflation were not among the leading determinants of REITs, and expected inflation did not affect REITs. Their marginal effects indicated that REITs increased at significant levels when unexpected inflation was positive. However, the return of REITs was not sensitive to unexpected negative inflation, showing an asymmetry in the connection between the return of REITs and unexpected inflation. 


\section{DATA AND METHODOLOGY}

\subsection{Methodology}

The effects of macroeconomic factors on the stock market performance of REITs were analyzed with a panel regression model in the present study. Panel data estimation methods are performed with pooled, fixed and random effects. Pre-tests are required to determine which method to choose (Baltagi, 2005: 34-35). Chow and Breush-Pagan's (BP) tests were applied for the panel regression estimation process in the first step, and Ho was rejected. In the other step, the Fixed Effects Model (FEM) was decided by applying the Haussmann test. Also, when this model was analyzed, different solution algorithms were tried, and the "Cross section SUR algorithm", which yields the smallest total squared error value, was employed. The cross-section dependency and homogeneity tests were applied before the panel data analysis, and it was determined as a result of the first and second generation unit root tests that the variables were stationary I (1) for first order difference. In this way, the panel regression model was estimated by taking the first-order differences.

$$
M V / B V_{i t}=\beta 0+\beta 1 \text { HouseInterestRate }_{i t}+\beta 2 \text { IncomePerCapita }_{i t}+\beta 3 \text { Inflation }_{i t}+\varepsilon_{i t}
$$

\subsection{Data}

A total of 33 Real Estate Investment Trusts traded in Borsa Istanbul constituted the universe of the analyses. However, when these REITs were examined, it was found that the less traded companies increased the variability, and did not represent the mean values. For this reason, a total of 27 REITs were selected, and 6 REITs were excluded, and the sampling was formed in this way. The panel regression analysis was applied in the analyses on the basis of quarterly data for the period [2014.Q1-2020.Q2].

Table 1: Variables Considered in Panel Regression

\begin{tabular}{|l|l|}
\hline Variables & Definition \\
\hline Housing Interest Rates (\%) & Independent Variable \\
\hline Income Per Capita (\$) & Independent Variable \\
\hline Inflation (\%) & Independent Variable \\
\hline MV/BV Ratio & Dependent Variable \\
\hline
\end{tabular}

\subsection{Analysis and Results}

Homogeneous or heterogeneous variables change the form of the unit root and cointegration tests to be applied (Hsiao, 2003: 56). The Homogeneity Test which was improved by Pesaran \& Yamagata (2008) and Pesaran et al. (2008) provides guidance on which ones to use in first generation unit root tests. Besides, if there is a cross-section dependency, it is necessary to apply second generation unit root tests (Wooldridge, 2010: 138). In the present study, as there were 27 companies $(N=27)$ and 26 quarters $(T=26)$, it was determined with the Pesaran (2004) CDLM test when the time dimension was smaller than the cross-section dimension $(\mathrm{T}<\mathrm{N})$.

Table 2: Cross Section Dependency and Homogeneity Test Results

\begin{tabular}{|l|c|c|c|c|}
\hline & $\begin{array}{c}\text { CD }_{\mathbf{L}} \\
\text { Test Statistics }\end{array}$ & $\begin{array}{c}\text { LMadj } \\
\text { Test Statistics }\end{array}$ & $\begin{array}{c}\text { CD } \\
\text { p Value }\end{array}$ & $\begin{array}{c}\text { LMadj } \\
\text { p Value }\end{array}$ \\
\hline Housing Interest Rates & 6.953 & 9.372 & 0.001 & 0.002 \\
\hline Income Per Capita & 9.103 & 10.583 & 0.000 & 0.000 \\
\hline Inflation & 9.335 & 10.736 & 0.009 & 0.005 \\
\hline MV/BV Ratio & 9.459 & 10.044 & 0.000 & 0.000 \\
\hline Coefficient Homogeneity Test Statistic Value & \multicolumn{2}{|c|}{$\Delta=16.382$} & \multicolumn{2}{c|}{$p=0.000$} \\
\cline { 2 - 5 } & \multicolumn{2}{|c|}{$\Delta_{\text {adj }}=19.448$} & \multicolumn{2}{c|}{$p=0.001$} \\
\hline
\end{tabular}

As the probability values of the test results were less than $5 \%$, the Null Hypothesis (slope coefficients were homogeneous) was rejected, and it was found that the coefficients were heterogeneous. The cross-sectional dependency was also determined between units $(p<0.05)$. First generation unit root tests were divided into two as homogeneous and heterogeneous models. As the coefficients were heterogeneous, first generation unit root tests were used with Im, Pesaran and Shin (2003), Maddala and Wu (1999), Choi (2001) based on the heterogeneous model assumption.

Table 3: First Generation Panel Unit Root Test Result

\begin{tabular}{|l|c|c|c|c|c|c|}
\hline \multirow{3}{*}{ Financial Ratios } & \multicolumn{2}{|c|}{ Maddala \&Wu Test } & \multicolumn{2}{c|}{ Im, Pesaran \& Shin Test } & \multicolumn{2}{c|}{ Choi Test } \\
\cline { 2 - 7 } & Level & $\begin{array}{c}\text { 1. Level } \\
\text { Difference }\end{array}$ & Level & $\begin{array}{c}\text { 1. Level } \\
\text { Difference }\end{array}$ & Level & $\begin{array}{c}\text { 1. Level } \\
\text { Difference }\end{array}$ \\
\cline { 2 - 7 } & Trend+Constant & Constant & Trend+Constant & Constant & Trend+Constant & Constant \\
\hline Housing Interest Rates & -0.963 & $-6.473^{*}$ & -1.152 & $-7.683^{*}$ & -1.156 & $-8.263^{*}$ \\
\hline Income Per Capita & -1.362 & $-8.328^{*}$ & -1.401 & $-8.661^{*}$ & -1.283 & $-9.238^{*}$ \\
\hline
\end{tabular}




\begin{tabular}{|l|l|l|l|l|l|l|}
\hline Inflation & -0.885 & $-5.902^{*}$ & -0.990 & $-7.409^{*}$ & -1.084 & $-8.606^{*}$ \\
\hline MV/BV Ratio & -1.134 & $-7.445^{*}$ & -1.217 & $-8.113^{*}$ & -1.278 & $-9.114^{*}$ \\
\hline
\end{tabular}

* Constant variable for 0.05 .

It was determined as a result of the panel unit root tests that the variables for the first level difference were I (1), i.e., stationary. In this case, the analysis was made by taking the first level differences. If there was cross-section dependency in panel data, using second-generation unit root tests yields more consistent, efficient, and powerful estimations. In the present study, second generation unit root tests must be used, because cross-sectional dependence was determined (Özel et al., 2013: 168). CADF, which is one of the second generation unit root tests, was used in this respect. The results of the CADF test which was developed by Pesaran (2007) are given in Table 4.

\section{Table 4: Panel CADF Unit Root Test Results}

\begin{tabular}{|l|c|c|c|c|}
\hline \multirow{2}{*}{ Variables } & \multicolumn{2}{|c|}{ Level } & \multicolumn{2}{c|}{$\mathbf{1}^{\text {st }}$ Level Difference } \\
\cline { 2 - 5 } & Constant & Constant + Trend & Constant & Constant + Trend \\
\hline Housing Interest Rates & -0.945 & -1.109 & $-8.219^{*}$ & $-8.617^{*}$ \\
\hline Income Per Capita & -8.733 & -0.957 & $-9.277^{*}$ & $-9.558^{*}$ \\
\hline Inflation & -1.102 & -1.216 & $-8.618^{*}$ & $-9.104^{*}$ \\
\hline MV/BV Ratio & -1.231 & -1.355 & $-7.454^{*}$ & $-7.916^{*}$ \\
\hline
\end{tabular}

* Constant variable for 0.05 .

The maximum lag length was taken as 2 in CADF tests, and the optimal lag length was identified according to the Schwarz information criterion. It was seen that the Null Hypothesis was rejected at a 5\% significance level. The unit root test results showed that the series was not stationary at the level, i.e., they had a unit root, and the variables were stationary at the I (1) level. In this case, regression analysis was made with first-order differences. Chow and Breush-Pagan's (BP) tests were applied in the first step for the panel regression estimation process. For the Chow test, the $\mathrm{H}_{0}$ hypothesis was the Pooled Regression, the $\mathrm{H}_{1}$ hypothesis was the Fixed Effects Model (FEM), and the $\mathrm{H}_{0}$ hypothesis was pooled regression for the BP test, and the $\mathrm{H}_{1}$ random-effects model (TEM) (Bayar \& Sezgin, 2017: 55).

Table 5: Panel Regression Prediction Method Selection Test Results

\begin{tabular}{|l|c|c|}
\hline Test & Probability $(\mathbf{p})$ & Decision \\
\hline Chow $(\mathrm{F}$ test $)$ & 0.003 & $\mathrm{H}_{0}$ rejected \\
\hline $\mathrm{BP}\left(\mathrm{X}^{2}\right.$ test $)$ & 0.007 & $\mathrm{H}_{0}$ rejected \\
\hline
\end{tabular}

As shown in the table above, the $\mathrm{H}_{0}$ hypothesis was rejected for both tests. For this reason, it was necessary to make a choice between TEM and FEM models. In this case, selection will be made for two models with the help of the Haussmann test. The hypotheses of this test are given below, and the test results are seen in Table 6. $\mathrm{H}_{0}$ : Incidental effect (TEM), $\mathrm{H}_{1}$ : No incidental effect (FEM).

Table 6: Haussmann Test Result

\begin{tabular}{|l|c|c|c|}
\hline Test Summary & Chi-Square Statistics & Chi-Square s.d. & Probability (p) \\
\hline Cross-Section Random & 894.267 & 2 & 0.000 \\
\hline Period Random & 917.316 & 2 & 0.000 \\
\hline Cross-Section and Period Random & 995.428 & 2 & 0.000 \\
\hline
\end{tabular}

According to the results of the Haussmann test, the $\mathrm{H}_{1}$ hypothesis was accepted, and the FEM model was decided. Also, when this model was analyzed, different solution algorithms were tried, and the "Cross section SUR algorithm", that yielded the smallest total squared error value, was used.

Table 7: Panel Regression Estimation Results

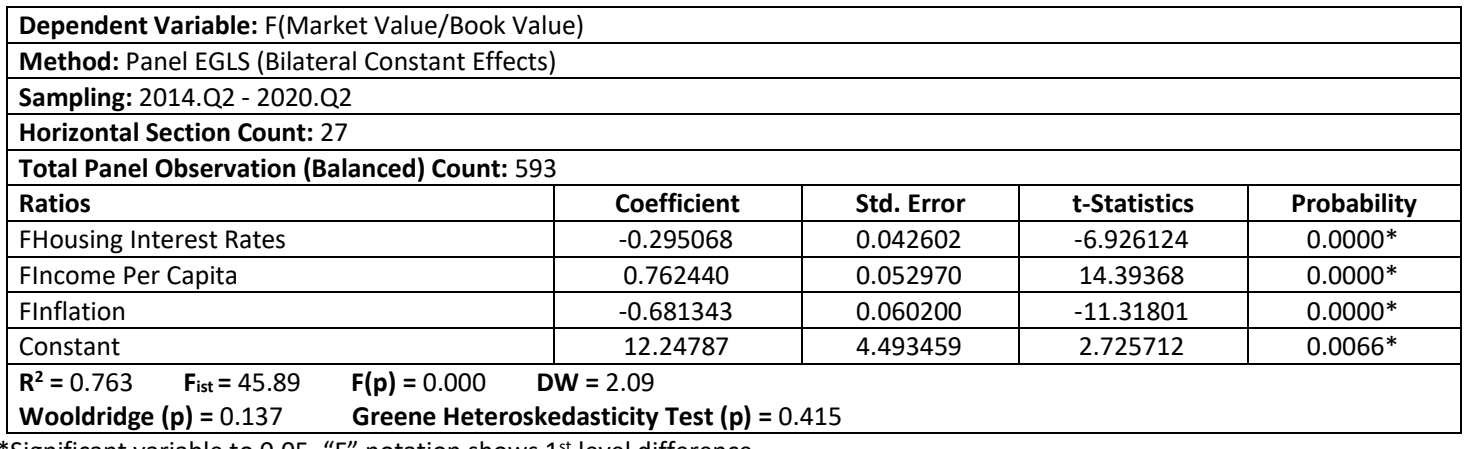

*Significant variable to 0.05 , “F" notation shows $1^{\text {st }}$ level difference. 
As seen in the regression outputs, the independent variables had $76.3 \%$ explanatory power for the MV/BV variable. Significant panel regression estimation results are listed briefly according to the coefficient sizes as the biggest effect on significant variables was income per capita. When income per capita increased by 1 unit, the MV/BV variable increased by 0.762 unit. When the inflation rate increased by 1 unit, the MV/BV variable decreased by 0.681 units. When the housing interest rate increased by 1 unit, the MV/BV ratio increased by 0.295 units. To test the assumptions of the model, the Wooldridge (2002) Autocorrelation Test was applied, and it was determined that there were no autocorrelations. As a result of the Greene Heteroscedasticity Test, the presence of homogeneity was determined, and it was found that the model resulted in which the assumptions were provided were interpretable.

\section{CONCLUSION}

The present study aimed to uncover the effects of macroeconomic variables on stock market performances for REITs, which are the basic building blocks of the real estate and construction sectors with an important place in our country. It was determined as a result of the analyses that as per capita income increased, MV/BV values also increased, but inflation and housing interest rates decreased the MV/BV ratio. It was also found that income per capita was the most influential variable on stock market performance. Expectations about the change in permanent income per capita were also determined in the choice of property or rental housing. For this reason, households consider permanent incomes in decisions about housing demands; and it is very important to consider permanent income in the measurement of income elasticity. Previous studies evaluated regional and national housing market data regarding the income elasticity of housing demand. It is expected that there will be positive relations between income per capita and housing demand and house prices, which is also true for REIT performance. The rise and fluctuation of inflation rates play active roles in investment decisions because they are an important uncertainty factor about the future. Increased housing prices above the rate of increase in inflation cause the perception that housing capital is the best investment tool against fluctuations in prices, which, in return, increases the demand for housing. According to the risk aversion theory that was developed by Fama and Schwert (1977), investments should be distributed in a balanced and careful manner among different financial assets to protect the assets (i.e. savings) and make the best use of them. Also, it should not be ignored that inflation is a factor eroding the value of the assets owned in this respect, especially assets resistant to inflation should be preferred. Real estate has an important place among the assets resisting to inflation. However, investors cannot always access real estate, and may not prefer it because it has low short-term returns and/or requires a large amount of investment. The change in housing interest rates changes housing demands and the financial power determining the housing purchase because housing prices will be affected by the cost of financing. In general terms, there are negative relations between interest rates and housing prices because of the decreasing demand. Household disposable income and adequate borrowing in financial markets depend on long-term low interest rates and favorable credit terms because household housing investments are dependent heavily on borrowed funds; and therefore, interest rates play important roles in directing housing prices and housing investments.

When a general evaluation is made, it can be speculated that policy makers must implement policies to increase the development of the stock market and its contribution to economic growth; and to do this, they must also perform structural reforms aimed at managing the undesirable current developments in macro variables. However, the fact that the factors affecting stock returns may not remain the same in the long run is considered, it may be proper to examine the effects of these variables along with other macroeconomic factors and different econometric methods in future studies. The perception that REITs cannot yield adequate demand in Borsa Istanbul, and therefore, there is a relatively shallow market in terms of depth, has not yet changed. There are problems in finding financial resources and developing alternative capital market instruments because capital investments are not mature enough in developing or underdeveloped countries. However, the financial sector is the driving force of a country, and the savings of the savers are taken into the economy. Real estate-related sectors have a great weight in the economy all over the world. Real estate-based financial instruments must be diversified in Turkey to benefit from these valuable investment instruments.

\section{REFERENCES}

Ambrose, B. W. \& Linneman, P. (2001). REIT organizational structure and operating characteristics. Journal of Real Estate Research, 21(3): 141-162. https://doi.org/10.1080/10835547.2001.12091049

Agnello, L., Castro, V., \& Sousa, R. M. (2018). Economic activity, credit market conditions, and the housing market. Macroeconomic Dynamics, 22(7): 1769-1789. https://doi.org/10.1017/S1365100516000869

Baltagi, B. H. (2005). Econometric Analysis of Panel Data. 3rd edition. West Sussex: John Wiley \& Sons Ltd.

Bayar Y. \& Sezgin H. F. (2017). Trade openness, inequality and poverty in Latin American countries. Ekonomika (Economics), 96(1): 47-57. https://doi.org/10.15388/ekon.2017.1.10663

Chang, KL., Chen, NK. \& Leung, C.K.Y. (2011). Monetary policy, term structure and asset return: Comparing REIT, housing and stock. The Journal of Real Estate Finance and Economics, Springer, 43(1): 221-257. https://doi.org/10.1007/s11146-010-9241-8

Choi, I. (2001). Unit root tests for panel data. Journal of International Money and Finance, 20(2): 249-272. https://doi.org/10.1016/S02615606(00)00048-6

Ewing, B. T., \& Payne, J. E. (2005). The response of real estate investment trust returns to macroeconomic shocks. Journal of Business Research, 58(3): 293-300. https://doi.org/10.1016/S0148-2963(03)00147-4

Fama, E. F. \& Schwert, G. W. (1977). Asset returns and inflation. Journal of Financial Economics, 5(2): 115-146. https://doi.org/10.1016/0304$\underline{405 X(77) 90014-9}$ 
Hsiao, C. (2003). Analysis of Panel Data (2nd ed., Econometric Society Monographs). Cambridge: Cambridge University Press.

Hussin, M.Y.M., Muhammad, F., Razak, A. A., Hadi, F.S.A., \& Gan, P-T. (2017). The role of macroeconomic variables in the Islamic real estate investment trusts (I-REIT) market in Malaysia. The International Journal of Academic Research in Business and Social Sciences, 7(4): 911-926. https://doi.org/10.6007/IJARBSS/V7-14/2901

Im, K. S., Pesaran, M. H., \& Shin, Y. (2003). Testing for unit roots in heterogeneous panels. Journal of Econometrics, 115(1): 53-74. https://doi.org/10.1016/S0304-4076(03)00092-7

Kirui, E., Wawire, H. W. \& Onono, P. (2014). Macroeconomic variables, volatility and stock market returns: a case of Nairobi securities exchange, Kenya. International Journal of Economics and Finance, 6 (8): 214-228. http://dx.doi.org/10.5539/ijef.v6n8p214

Linck, L. (2016). Stock returns, macroeconomic variables and expectations: Evidence from Brazil. Pensamiento Y Gestión, (40): 91-112. https://doi.org/10.14482/pege.40.8806 Retrieved from https://www.redalyc.org/jatsRepo/646/64646279004/html/index.html

Loo, W. K., Anuar, M. A., \& Ramakrishnan, S. (2016). Integration between the Asian REIT markets and macroeconomic variables. Journal of Property Investment \& Finance, 34(1): 68-82. https://doi.org/10.1108/JPIF-12-2014-0070

Maddala, G. S. \& Wu, S. (1999). A comparative study of unit root tests with panel data and a new simple test. Oxford Bulletin of Economics and Statistics, Special Issue, 61(S1): 631-652. https://doi.org/10.1111/1468-0084.0610s1631

Marfatia, H. A., Gupta, R., \& Cakan, E. (2017). The international REIT's time-varying response to the US monetary policy and macroeconomic surprises. The North American Journal of Economics and Finance, 42: 640-653. https://doi.org/10.1016/j.najef.2017.09.007

Nishigaki, H. (2007). An analysis of the relationship between US REIT returns. Economics Bulletin, 13(1): 1-7. Retrieved from http://citeseerx.ist.psu.edu/viewdoc/download?doi=10.1.1.498.2113\&rep=rep1\&type=pdf

Ozel, H. A., Sezgin, F. H. \& Topkaya, Ö. (2013). Investigation, of economic growth and unemployment relationship for G7 countries using panel regression analysis. International Journal of Business and Social Science, 4(6): 162-170. Retrieved from

http://ijbssnet.com/journals/Vol 4 No 6 June 2013/20.pdf

Pesaran, M. H. (2004). General diagnostic tests for cross section dependence in panels. CESifo Working Papers, No. 1229: 1-40. https://doi.org/10.17863/CAM.5113 Retrieved from https://www.cesifo.org/en/publikationen/2004/working-paper/general-diagnostictests-cross-section-dependence-panels

Pesaran, M. H. (2007). A simple panel unit root test in the presence of cross-section dependence. Journal of Applied Econometrics, 22(2): 265-312. https://doi.org/10.1002/jae.951

Pesaran, M. H. \& Yamagata, T. (2008). Testing slope homogeneity in large panels. Journal of Econometrics, 142 (1): 50-93. https://doi.org/10.1016/j.jeconom.2007.05.010

Pesaran, M. H., Ullah A., \& Yamagata T. (2008). A bias-adjusted LM test of error cross-section independence. Econometrics Journal, 11 (1): 105-127. https://doi.org/10.1111/j.1368-423X.2007.00227.x

Pierdzioch, C., Risse, M., Gupta, R., \& Nyakabawo, W. (2018). On REIT returns and (un-)expected inflation: Empirical evidence based on Bayesian additive regression trees. Finance Research Letters, Elsevier, 30 (C): 160-169. https://doi.org/10.1016/j.frl.2018.09.010

Wong, W. W. (2017). The macroeconomic forces that drive REIT returns in Australia. ERES 2017: 24th Annual Conference of the European Real Estate Society, 1-14. Retrieved from https://eres.architexturez.net/system/files/P 20170115032427 715.pdf \& https://eres.architexturez.net/system/files/183.pdf

Wooldridge, J. M. (2010). Econometric Analysis of Cross Section and Panel Data. 2nd edition. Cambridge, Massachusetts, London, England: The MIT Press.

Zugul, M., \& Sahin, C. (2015). Faiz oranı ve enflasyonun gayrimenkul yatırım ortaklığı getirisi üzerindeki etkisine yönelik bir uygulama. Akademik Bakış Dergisi, (49): 147-162. Retrieved from https://dergipark.org.tr/tr/pub/abuhsbd/issue/32942/366009 